\title{
Freshwater Lens, Settlement Patterns, Resource Use and Connectivity in the Marshall Islands
}

\author{
Transforming Cultures eJournal, \\ Vol. 1 No. 2, June 2006 \\ http://epress.lib.uts.edu.au/journals/TfC
}

\author{
Dirk HR Spennemann \\ Institute of Land, Water and Society \\ Charles Sturt University
}

\begin{abstract}
Life on coral atolls can be very precarious. The sand cay islets are low-lying (in the main less than $2 \mathrm{~m}$ above high water) and small. Only the larger islands (over $500 \mathrm{~m}$ by $1000 \mathrm{~m}$ ) are suitable for permanent human habitation, as they possess a fragile lens of freshwater floating on top of a saltwater base. It is this lens of groundwater that allows for a variety of plant life, and it is this source of fresh water that allows humans to exist on the island. Environmental disasters, such as typhoons with waves of over 10m washing across an entire islet, can swamp the groundwater lens with saltwater, causing salinisation and thus imperilling human survival.
\end{abstract}

To reduce the consequences of the environmental disasters, Marshallese chiefs had land holdings scattered over several islands of the same atoll, as well as land rights and, importantly, rights to resources, on other atolls. In times of disaster there were thus other resources to call upon. That level of connectivity allowed the Marshallese society to thrive on the marginal land they inhabited.

\section{Introduction}

Several papers in this journal have explored the human responses to living near shorelines which form the boundaries between the sea and the land, between fresh and saltwater environments. There are, however, areas where the sea prevails both in expanse and in day-to-day presence, while the land is marginal and human life is precariously balanced. Human life on the small islets that make up the atolls in the world's oceans is dependent on the presence of potable fresh water, while at the same time is imperilled by the ever-present threat of the sea inundating the low-lying islands. In response to these threats, island societies have developed response mechanisms that ensure, to the extent feasible, human and societal survival. 
This paper describes the situation on the Marshall Islands, a small atoll nation comprising 29 atolls and 5 islands, located in the north-west equatorial Pacific, about $3,790 \mathrm{~km}$ west of Honolulu, 2,700km north of Fiji and 1,500km east of Ponape. With the exception of the two northwestern atolls, Enewetak and Ujelang, the Marshall Islands are arranged in two island chains running roughly NNW to SSE: the western Ralik Chain and the eastern Ratak Chain (figure 1). ${ }^{1}$ Unlike the high volcanic islands of Hawaii or Fiji, the atolls of the Marshall Islands are a series of low-lying sand cays with a maximum natural elevation not exceeding $3 \mathrm{~m}$.

\section{Geomorphology}

The principal agent supporting life on atolls is the small freshwater lens on each of the islets that stud the atoll rim. To understand the nature of the lens, some geomorphology is required.

Live coral originally formed barrier reefs around raised islands. Once the island's core gradually submerged, the coral continued to grow, effectively forming rings of coral in the sea. The shape of the atoll reflects the original shape of the barrier reef. The atolls can be as small as Taka Atoll with only $0.6 \mathrm{~km}^{2}$ combined land area or as large as Kwajalein Atoll, the world's largest atoll with a lagoon area of $2,174 \mathrm{~km}^{2}$ but only 16.4 $\mathrm{km}^{2}$ combined landmass. ${ }^{2}$ The atolls rise steeply from the ocean floor, often over $1500 \mathrm{~m}$, and slope gently into the lagoon, which is commonly not any deeper than 40$80 \mathrm{~m}$. Water exchange between the lagoon and the sea is maintained through passes, as well as across the reef platform at high tide.

The only parts of an atoll that are permanently above mean high seawater level are the sand cays or islets, made up from erosion products of the reef, predominantly calciferous sand and coral rubble. The particle size of the material decreases from the ocean side to the lagoon side.

In addition, there is variation between the islets of an atoll depending on the location of the islet in relation to prevailing wave action. Islets on the leeward side of the atoll tend

\footnotetext{
${ }^{1}$ Figures are found at the end of the essay.

${ }^{2}$ Bryan, E.H. (1971) Guide to Place names in the Trust Territory of the Pacific Islands (the Marshall, Caroline and Marina Islands). Honolulu: Bishop Museum, Pacific Science Information Center.
} 
to be larger and have finer sediments, while islets exposed to the swell, and more likely to be water-washed during strong storms, tend to have more coarse-grained sediments.

\section{Freshwater Lenses}

Because of the total lack of physical elevation and hence orthographic rainfall patterns, the precipitation in the Marshall Islands is solely governed by the general Pacific-wide climatic belts as well as by highly localised micro-climatic rainfall over the lagoons. On the regional scale, there is a distinct precipitation gradient running from the equatorial zone in the south to the north (Figure 2). The further north the atoll is located, the less precipitation can be expected. Thus Jaluit, located at $5^{\circ} 47^{\prime} \mathrm{N}$ has a precipitation of almost $4000 \mathrm{~mm}$ per annum, while Wake, located at $19^{\circ} 28^{\prime} \mathrm{N}$ has only a precipitation of less than $1000 \mathrm{~mm}$ per annum. ${ }^{3}$ Intense tropical storms of short duration contribute to much of the total rainfall, and the incidence of the storms themselves is quite variable from one year to the next for a particular island or atoll.

Any rain that is deposited on the atoll is dependent on the vicariousness of the clouds. In many instances, especially during the drier season, rain-bearing clouds may be seen to pass over a particular stretch of land, but may miss another completely, or discharge into the lagoon. Unless rain falls on an islet is of no use to the land ecosystem.

The flat landscape, permeability of the underlying rock, and the composition of soils and reef-derived sediments prevent the occurrence of streams or creeks. Therefore, after the wetting loss, i.e. the amount of moisture needed to wet the surfaces of plants (and roofs etc) and to evaporate, all of the rainfall dropping on a given islet will percolate through the sand and settle into the ground. As rainwater has a lower specific gravity than saltwater, the rainwater will in effect 'float' on top of the saltwater. ${ }^{4}$ Moreover, because of weight, it will gradually depress the surface of the saltwater, creating a lensshaped region of fresh-water. As the lens grows, some of the lens will run out at the

\footnotetext{
${ }^{3}$ Williamson, I. \& M.D. Sabath (1982) "Island population, land area, and climate: A case study of the Marshall islands", Human Ecology 10(1): 71-84; Spennemann, Dirk H.R. (1992) "Makmõk. Notes on the occurrence, utilisation, and importance of Polynesian Arrowroot (Tacca leontopetaloides) in the Marshall Islands". Republic of the Marshall Islands Ministry of Internal Affairs / Ministry of Social Services Occasional Paper $N^{\circ}$ 1. Majuro, Marshall Islands: Ministries of Internal Affairs and Social Services.

${ }^{4}$ Ghyben-Herzberg principle; Drabbe, J. \& W. Badon Ghijben (Ghyben) (1889) "Nota in verband met de voorgenomen putboring nabij Amsterdam" Tijdschrift van het Koninklijk Instituut van Ingenieurs Verhandelingen (1888/1889) pp 8-22; Herzberg, A. (1901) "Die Wasserversorgung einiger Nordseebäder”, Journal für Gasbeleuchtung und Wasserversorgung 44: 815-819; 842-844.
} 
edges of the islet (Figure 3). As there is no wave action inside the islet's core, the integrity of the lens is maintained. Limited mixing of the salt and fresh-water will occur at the boundaries of the lens, caused by water-level fluctuations as a function of the tidal movement or as convective forces due to capillary action. The underlying substrate is not homogenous however, as it is made up of the old reef platform with various coral heads, intermixed with now consolidated but formerly loose sediment that accumulated between the coral. Thus the 'storage capacity' of different substrates will differ. ${ }^{5}$

As rain falls on the islet, the lens will become thicker, with the interface with the seawater being gradual. The shape of the island determines the thickness of the lens. Ignoring any variations in the coral limestone substrate, the thickest possible lens would result from a circular island. As the island's shape on atolls is either oblong or triangular of some description, the greatest thickness of the lens is predetermined by the width of the island (Figure 4).

\section{Vegetation Patterns}

The freshwater lens provides a stable water supply for any vegetation growing on the islet. On small and very low-lying islets the vegetation is limited to hardy shrubs that can withstand both the salt spray from the ocean and can thrive on a supply of brackish water. On the larger islets, the freshwater lenses allow other vegetation to grow, such as breadfruit (Artocarpus altilis) which are dependent on non-saline water. The gradation of the soil/sand substrate, availability of freshwater, wind, wave action and the concomitant salt spray cause the vegetation on the sand cays of the coral atolls to occur in clearly defined zones, reaching from the lagoon side to the ocean side of the island.

The vegetation on islands of the coral atoll is thus laid out in clearly defined vegetational zones changing from the lagoon to the oceanside (Figure 5). The ocean shore consists of a broadleaf forest with salt-spray resistant broadleaf plants. The soil is very well drained, cobbly to gravely in nature and not conducive to the growth of many plants. The only major food plant to grow there is Pandanus (Pandanus tectorius). The lagoonal zone shows a fringe of coconut palms and other shore vegetation, as well as

\footnotetext{
5 Arnow, T. (1954) “The Hydrology of the Northern Marshall Islands", Atoll Research Bulletin 30: 1-7; Cox 1951; Anthony, Stephen S., Peterson, Frank L., Mackenzie, Fred T. \& Hamlin, Scott N. (1989) "Geohydrology of the Laura fresh-water lens, Majuro atoll: A hydrogeochemical approach", Geological Society of America Bulletin 101(8): 1066-1075; Wheatcraft, S. W. \& Buddemeier, R. W. (1981) "Atoll island hydrology", Ground Water 19(3): 311-320.
} 
some low broadleaf trees and Pandanus, all growing in a soil of fine sand with good drainage. The centre of the island also sees a fine grained soil, with a gradual increase of rubble towards the ocean shore. Given the decay of vegetation in that area and the stability of the island in its centre, a thick fertile soil can built up, which, coupled with easily accessible permanent freshwater sources, i.e. the freshwater lens, allows many trees, particularly breadfruit trees to grow well. It is consequently called the 'breadfruit zone.' Furthermore, the fertility of the soil and the closeness of the freshwater lens permits the establishment of swamp taro (Cyrtosperma chamissionis) plantations in excavated taro pits. $^{6}$

The vegetation zonation on any given island depends on the island's location on the atoll, with leeward islands, away from the swell and strong salt spray, being generally more conducive to complex vegetation patterns than windward islands. Moreover, as stated, the latitude of the atoll determines the overall rainfall, which in turn has implications on the viability of vegetation.

\section{Settlement Patterns and Land Ownership}

The low-lying sand islands of the coral atolls are exposed to environmental hazards and changing conditions. Therefore, the atoll environment faced by the prehistoric, early historic and also the present-day settlers of the Marshall Islands, defines very clearly the way their settlements, their horticultural (agricultural) sites and their ritual sites, such as cemeteries, are arranged on any island of a given atoll. The environmental parameters to be considered are:

- availability of freshwater

- availability of gardenable/arable land

- availability of a protected anchorage for boats

- availability of a protected area for housing

\footnotetext{
${ }^{6}$ Summarised from Fosberg, F.R. (1990) "A review of the Natural History of the Marshall Islands", Atoll Research Bulletin 330. Washington: Smithsonian Institution; Spennemann, Dirk H.R. (1990) Cultural Resource Management Plan for Majuro Atoll, Republic of the Marshall Islands. 2 Vols. Report prepared in fulfilment of U. S. Department of Interior, Office of Territorial and International Affairs Technical Assistance Grant MAR-42. Report submitted to the Historic Preservation Office, Majuro, Republic of the Marshall Islands. August 1990, (printed 1992).
} 
Given the zonation of the vegetation on any given island, the traditional land divisions, the wato, were laid out as strips of land running from the ocean side of the islet to its lagoon side, thereby ensuring that each household had access to all environmental zones. Figure 6 shows the modern pattern at the left, and the reconstructed prehistoric patterns at the right (after Spennemann 1990). The wato on larger islets, especially on the environmentally favoured, southern atolls, are narrower than on the smaller islets of the same atolls. On the drier and thus less favourable northern atolls the wato are wider.

The prehistoric settlement pattern is almost entirely defined by these environmental constraints. Archaeological and historical site surveys found that the settlement on a major southern atoll, such as Majuro, favours larger islands. The coral gravel spreads, indicating house sites, were concentrated on the larger islands, and where a more detailed analysis was possible, it was found that the settlements were located on both sides of the breadfruit zone, with the main settlements on the lagoonal side. The habitation sites would begin some 30-50m inland from the present lagoonal edge, well above the storm high tide mark and behind a small natural strand wall. Going inland, these gravel spreads would gradually change to shell middens, indicating cooking facilities and associated rubbish dumps on the inland, the "backward" side of the houses. Inland of these rubbish heaps an area of burials is encountered, located between the houses and the gardening centre. In the fertile middle of the island the breadfruit trees and a dense zone of taro patches are found. Going towards the ocean side one would encounter another, narrower zone of habitation and then would get into a dense salt resistant shrub and broadleaf forest fringing the ocean shore. In this zone some burials can also be expected. ${ }^{7}$

The settlement patterns described for a fertile, ideal atoll islet in the southern Marshalls is open for modifications in other parts of the Marshall Islands. A decreasing variety in plant life, and correlated with this a decreasing availability of food, are directly related to decreasing rainfall intensity the further north an atoll is located. On Ailuk Atoll, for example, the climate is too dry for breadfruit trees (Artocarpus altilis) to exist. The food available to the people on that atoll is restricted to coconuts (Cocos nucifera), Pandanus and arrowroot (Tacca leontopetaloides). Further north, such as on Bikar, the climate is

\footnotetext{
${ }^{7}$ Spennemann, Dirk H.R. (1992); Spennemann, Dirk H.R. (1999) "No room for the dead. Burial practices in a constrained environment", Anthropos 94(1): 35-56.
} 
too dry for coconut palms and Pandanus to exist. It is not surprising that Bikar was apparently never settled on a permanent basis.

\section{Vicariousness of Existence}

The single most destructive climatological phenomenon affecting atolls are typhoons ('cyclones' south of the equator). These high-speed circular wind systems are created around a central area of low air pressure. Spawned as tropical depressions in areas of warm seawater, located at the interface between two opposing air currents, these systems can pick up wind speed and thus strength if the required movement of air in the central column is sustained over a long period, and if a strong jet stream overhead creates a sucking motion. Tropical storms of gale force have sustained wind speeds (for ten minutes or more) of $88 \mathrm{~km} / \mathrm{h}$ and can develop into typhoons with minimum sustained wind speeds of $117 \mathrm{~km} / \mathrm{h}$. Sustained wind speeds of close to $200 \mathrm{~km} / \mathrm{h}$ are not uncommon among 'super typhoons.'

Topical storms and typhoons are the most frightening natural phenomenon, especially for those living on a coral atoll where the maximum elevation is rarely more than $2 \mathrm{~m}$ above sea-level. The waves associated with such events can be $10 \mathrm{~m}$ and more, on occasion compounded by tidal fluctuations. The damage to the islands varies. Lowlying islands and islets of the coral atolls, however, suffer both from wind effects and from inundation. Often the entire islet is awash. Not only does the inundation with saltwater contaminate the fragile freshwater lens within the islets, the wave action also suspends much of the topsoil, washing it away and filling the taro patches in the centre of the islets with saltwater and sediment.

Typhoons have been a fact of life for the people in Micronesia since the time of their initial settlement thousands of years ago. The vicariousness of (semi-)traditional life on an atoll is best illustrated by describing the impact of a particular typhoon that struck the southern Marshalls on 30 June 1905 and that is well documented in the German colonial records. ${ }^{8}$

\footnotetext{
${ }^{8}$ Spennemann, Dirk H. R. (2004) "Chamissos Blick auf die Südsee und die Rezeption der 'Reise um die Welt' im Südpazifischen Raum” in Mit den augen des Frenden. Adelbert von Chamisso-Dichter, Naturwissenschaffender, Weltreisender. Berlin; Gesellschaft für interregionalen Kulturaustauch .V. Berlin, pp. 142-162.
} 
On 30 June 1905 a strong typhoon passed over the southern Marshall Islands, severely affecting Nadikdik (Knox) $\left(6^{\circ} 20^{\prime} \mathrm{N} 172^{\circ} 10^{\prime} \mathrm{E}\right)$, Mile, Arno, Majuro and Jaluit Atolls. Other atolls, namely Aur $\left(8^{\circ} 12^{\prime} \mathrm{N} \quad 171^{\circ} 06^{\prime} \mathrm{E}\right)$, Maloelap $\left(8^{\circ} 40^{\prime} \mathrm{N} 171^{\circ} 00^{\prime} \mathrm{E}\right)$, Ailinglapalap, Ebon, and Ujelang were also affected but to a lesser degree. Over 227 Marshallese lost their lives on that day on the affected atolls, most of them on Nadikdik and Mile. Many more people were injured. Hardest hit was Nadikdik Atoll, located just to the southwest of Mile. This atoll was completely washed over, all inhabited islands completely reduced to the bare reef platform and the human population of that atoll (seventy people) completely extinguished save for two boys who, clinging to an uprooted breadfruit tree, survived a 24-hour drift voyage to the southern coast of Mile. ${ }^{9}$ Following the destruction of all food stocks and fruit on the trees, approximately another 90 people died during the subsequent months due to starvation. Immediately following the event, the lagoon of Mile and to a lesser extent that of Jaluit were reported to be congested with floating debris: trees, bushes, houses, broken canoes, wooden utensils and corpses. The concentration of drift material in the waters of the Marshalls during July and August 1905 was so high that it constituted a serious shipping hazard, making the very limited relief operations not any easier. The flooding of several islets by saltwater caused die back of fruit trees as well as the contamination of the freshwater lens. ${ }^{10}$

\section{Social Structure}

Given the vicariousness of human existence on a single atoll, it is not surprising that the Marshallese designed social structures that mitigated such impacts both within an atoll and between atolls. Marshallese society is matrilineal and matrilocal. ${ }^{11}$ The status and resource rights of the parents influenced the status and rights of the children, with the mother's rights and status being stronger. The Marshallese social structure at the time of contact as presented by Erdland ${ }^{12}$ saw four main tiers of increasing land ownership:

\footnotetext{
${ }^{9}$ Jeschke (1905).

${ }^{10}$ See Spennemann (2004) for further details.

${ }^{11}$ Erdland, Augustin (1909) "Die Stellung der Frauen in den Häuptlingsfamilien der Marshall Inseln", Anthropos 4:106-112; Erdland, Augustin (1912) "Die Eingeborenen der Marshall Inseln im Verkehr mit ihren Häuptlingen”, Anthropos 7: 559-565; Erdland, Augustin (1914) Die Marshall Insulaner. Leben und Sitte, Sinn und Religion eines Südsee-volkes. Anthropos Ethnologische Bibliothek. Bd. 2, Heft 1. Münster i[n] W[estfalen]: Aschendorffsche Verlagsbuchhandlung; Krämer, Augustin (1906). Hawaii, Ostmikronesien und Samoa. Stuttgart: Schweizerbartsche Verlagsbuchhandlung.

${ }^{12}$ Erdland (1914: 99 ff).
} 
i) kajur, commoners, effectively serfs, with rights to (some of) the resources on single allotment of land but no control over land management decisions;

ii) ledikdik (transliterated by Erdland as läadökdök) of common descent lines, but because of capacity elevated to 'adviser' to the chiefs with ownership rights to a single allotment of land, given to him by a buirak or irooj as feudal holding in perpetuity and inheritable by the next generation;

iii) buirak, of chiefly lineage but subordinate to the irooj with absolute rights to more than one allotment of land, usually on the same islet, but certainly on the same atoll, and rights to produce and resources from other allotments; and iv) irooj, high ranking chiefs, with absolute rights to more than one allotment of land, usually on the same atoll (on occasion on more than one atoll) and who exercised rights to produce and resources from allotments on other atolls.

The allotments were bounded by other allotments and the shorelines. Traditional rights extended as far into the lagoon or ocean as the chief could physically stand to fish. ${ }^{13}$ Given that fact that the shape of an islet was subject to continual change caused by the processes of erosion and accretion, such a stipulation makes a great deal of sense. If and when two islets merged, the boundary line was drawn at the locality of the actual merger.

The German colonial administration (1886-1914) intentionally, directly and indirectly, consolidated the hierarchical structure and the power position of the irooj. On the one hand it prohibited warfare as a legitimate means of altering the balance of power, while it also introduced a head tax in 1888 with consequences to the hierarchy. ${ }^{14}$ Levied on every Marshallese subject, the tax could be forcefully collected if those levied were to

\footnotetext{
${ }^{13}$ Erdland (1914).

${ }^{14}$ Sonnenschein, Franz (1888a) Verordnung, betreffend die Erhebung von persönlichen Steuern. Jaluit, 28 June 1888. Ms. on file German Colonial Records, Bundesarchiv Berlin; Sonnenschein, Franz (1888c) "Verordnung [des Kaiserlichen Kommissars] betreffend die Art der Steuererhebung". Jaluit, 28 September 1888", in G. Riebow, (1893) Die Deutsche Kolonialgesetzgebung. Sammlung der auf die deutschen Schutzgebiete bezüglichen Gesetze, Verordnungen, Erlasse und internationalen Vereinbarungen, mit Anmerkungen und Sachregister. Erster Theil bis zum Jahr 1892. Berlin: D. Reimer, p. 622; Biermann, Maximilian (1889) Verordnung [des Kaiserlichen Landeshauptmannes] betreffend die Erhebung von persönlichen Steuern. Jaluit, 15 October 1889. Ms. on file German Colonial Records, Bundesarchiv Berlin; Biermann, Maximilian (1890) "Verordnung [des Kaiserlichen Landeshauptmannes] betreffend die Erhebung von persönlichen Steuern". Jaluit, 17 April 1890, in G. Riebow, Die Deutsche Kolonialgesetzgebung. Sammlung der auf die deutschen Schutzgebiete bezüglichen Gesetze, Verordnungen, Erlasse und internationalen Vereinbarungen, mit Anmerkungen und Sachregister. Erster Theil bis zum Jahr 1892. Berlin: D.Reimer (1893), pp. 620-621.
} 
default. ${ }^{15}$ Whereas traditionally the irooj had only a share of the food and other produce, as well as a share of his people's labour the introduction of the head tax, payable in the main commercial export article of the Marshall Islands, copra, led to the development of a formal payment of the irooj's share in copra. As the German authorities collected the tax as well as purchased any other copra from the irooj rather than directly from the individuals, the power position of the irooj was strengthened and essentially formalised. As a result of these and other more subtle colonial changes, the traditional tenure structure has been collapsed into three levels: ${ }^{16}$

i) dri-jerbal, or workers, with ownership rights to aspects of a single allotment of land;

ii) alap, or 'land manager,' who has rights to more than one allotment of land, usually on the same islet, but certainly on the same atoll; and

iii) irooj, who had rights on one or more entire atolls, as well as rights to resources on other atolls.

In practical terms, the increased movement from the outer islands to the population centres has created a new fourth level: those people who have no traditional rights whatsoever to the land allotment they reside on, but who are tolerated as squatters subject to the approval and good will of the irooj.

In terms of the traditional structure, burial patterns reflect the social structure, inasmuch as only chiefs and people with ownership rights to the land were traditionally buried. The corpses of commoners were set adrift into the ocean. Since colonial times the right to burial on land has been extended to everyone. ${ }^{17}$

As the strength of the socio-political position of an irooj depended on his capacity to provide for his commoners, whom he needed in order to be able to wage war, an irooj was reliant on the productivity of the island and its people. The traditional societal structure with land ownership scattered over several islets of an atoll and resource rights

\footnotetext{
${ }^{15}$ Sonnenschein (1888b).

${ }^{16}$ Tobin, Jack E. (1952) "Land tenure in the Marshall Islands", Atoll Research Bulletin 11. Washington: Pacific Science Board, National Research Council; Tobin, Jack E. (1958) Land tenure patterns Trust Terrritory of the Pacific Islands. Volume 1. Land tenure in the Marshall Islands. Guam: Office of the Staff Anthropologist, Terrritory of the Pacific Islands.

${ }^{17}$ Spennmann (1990); Spennemann, Dirk H.R. (1999).
} 
to islets on other atolls, ensured that irooj and to a lesser degree buirak, had access to a range of natural resources. This was an effective strategy for both physical and social survival in a fluctuating environment. Because rainfall intensity varies not only between but also within atolls, the productivity of some of the land allotments was patchy, even without taking into account climatic extremes such as typhoons or drought. During times of devastation wrought by typhoons or extended drought, the spread of such land holdings was especially important as it ensured that carbohydrate food stuffs were available for redistribution to the starving community members (a typhoon devastated community cannot live on fish alone).

\section{Connectivity}

Traditional inter-atoll obligations are on record for the early contact period as well as for the early German colonial period. Traditional inter-atoll obligations existed throughout with islanders providing a share of produce to the higher ranking chief. Redistribution of wealth, and the flow of important items to the highest ranking chief, have been observed from early European contact times onwards (cf. redistribution of iron from Wotje to Aur). ${ }^{18}$ This could take on substantial dimensions. The German Otto Eisenhardt, ${ }^{19}$ stranded on Ailuk Atoll in 1871, for example reported that once a year most of the islanders would sail to another atoll, some 150 nautical miles distant (most likely Wotje Atoll) to pay their obligations in the form of food especially arrowroot starch $^{20}$ and dried Pandanus paste. ${ }^{21}$

Typhoon food shortages have always been a problem in the atolls, and traditionally in times of starvation people would "cash in" on inter-atoll alliances and would move part of the population to other atolls. We know, for example, that the following reciprocal obligations existed:

\footnotetext{
${ }^{18}$ Chamisso, Adelbert von (1836) Reise um die Welt mit der Romanzoffischen Entdeckungs-Expedition in den Jahren 1815-1818 auf der Brigg Rurik, Kapitain Otto v. Kozebue. Adalbert von Chamisso's Werke. Leipzig, Weidmann'sche Buchhandlung. 1842; Kotzebue, Otto von (1830) Neue Reise um die Welt in den Jahren 1823, 24, 25 und 26. Weimar, Wilhelm Hoffmann und St. Petersburg, J. Brief. 1830. 2 vols; Spennemann (2004).

${ }^{19}$ Eisenhart, Otto (1888) “Acht Monate unter den Eingeborenen auf Ailu (Marshall-Gruppe)", Aus allen Weltheilen 19, pp. 207-208, 223-226, 250-252.

${ }^{20}$ Spennemann, Dirk H.R. (1992).

${ }^{21}$ Krämer, A Augustin \& Hans Nevermann (1938) "Ralik-Ratak (Marschall Inseln)" in G.Thilenius (ed.), Ergebnisse der Südsee-Expedition 1908-1910. II. Ethnographie, B: Mikronesien. Vol. 11: Hamburg: Friedrichsen \& de Gruyter.
} 
The typhoon of 1857, which seems to have devastated Ebon Atoll, resulted in severe starvation and the move of some 800 people of a total of 1300 temporarily from Ebon to Jaluit Atoll. $^{22}$

The movement of people from Mile to Arno, and the supply of coconuts, Pandanus and breadfruit preserves from Arno and Majuro to Mile after the typhoon of 1905 indicates the perseverance of such a safety network. ${ }^{23}$

These contacts and reciprocal obligations were not random throughout the Marshall Islands. Any connectivity was derived from the productivity of the atoll, the proximity of the atolls to each other, and the sailing conditions encountered. Based on a variety of data ranging from historic accounts, linguistic analyses, epidemiological data as well as biogeographical information, ${ }^{24}$ the connectivity of the atolls of the Marshall Islands can be speculatively reconstructed for the contact period and before (i.e. the first half of the nineteenth century). The majority of the communications occurred within each of the two chains, with inter-chain communications very rare, except at the southern end. In part this is a factor of the greater population density on the southern atolls. ${ }^{25}$

\section{Connectivity and Settlement Patterns Today}

The centralised colonial governments which consolidated the position of the irooj on the one hand, and the paternalistic stance the colonial administrations took towards the Marshallese, ${ }^{26}$ relieved the irooj of most their traditional responsibilities to provide for their people in times of distress.

\footnotetext{
${ }^{22}$ Krämer \& Nevermann (1938: 30).

${ }^{23}$ Spennemann, Dirk H.R. (in prep). From Disaster to Disaster...The efforts of the German Colonial Administration in Micronesia to mitigate the effects of the typhoons of 1905 and 1907. Book manuscript.

${ }^{24}$ Compiled in Spennemann, Dirk H.R. (2005) "Traditional and nineteenth century communication patterns in the Marshall Islands", Micronesian Journal of the Humanities and Social Sciences 4(1): 25 51.

${ }^{25}$ Spennemann, Dirk H.R. (2000) "Historic Demographic Information for the Marshall Islands -- Period from 1891 to 1914", Albury: URL: <http:/marshall.csu.edu.au/hmtl/demography/1891.html>.

${ }^{26}$ For an exception see Spennemann, Dirk H.R. (1998) “An officer, yes; but a gentleman? A biographical sketch of Eugen Brandeis, Military adviser, imperial judge and administrator in the German Colonial Service in the South Pacific" Pacific Island Studies Monographs Vol. 21 Sydney: Centre of South Pacific Studies, University of New South Wales.
} 
Modern aid and emergency relief supplies, provided first by the colonial German administration $^{27}$ and today, even after independence, by the US Federal Emergency Management Agency, have obviated the need for such inter-atoll connectivity.

Moreover, modern-day food imports, as well sophisticated tapping of the fresh water lens, combined with desalination plants on some atolls, have allowed the population living on the atolls of the Marshall Islands (that is not counting the large number of Marshallese living in the USA) to swell to more than ten times the traditional carrying capacity $^{28}$ with human settlement having spread to areas traditionally only sparsely settled because of their low productivity and their exposure to typhoon events. ${ }^{29}$ This is in particular the case on Majuro, the current capital, and Kwajalein, a major US missile testing base.

While there is no longer an urgent need to maintain traditional settlement and connectivity patterns, the land rights generated by traditional custom, however, remain and have adapted to new economic circumstance. Current day irooj, for example, request, and obtain, their share of rental payments as well as shares of atoll-based incomes such as derived from compensation for the lease of some islands of Kwajalein Atoll to the US military. By reciprocal action, commoners can call on the irooj for permission to squat on irooj-controlled lands on Majuro and Kwajalein.

While water, although still a determining factor on the outer islands of the Marshall Islands, has lost its paramount importance for the functioning of Marshallese society, the survival of the Marshallese settlers in pre-European times provides testament to a communal, yet hierarchical, solution to overcome the environmental constraints of atoll existence.

\footnotetext{
${ }^{27}$ cf. Spennemann (2004) for partial history.

${ }^{28}$ Spennemann (1999).

${ }^{29}$ Spennemann (1996).
} 


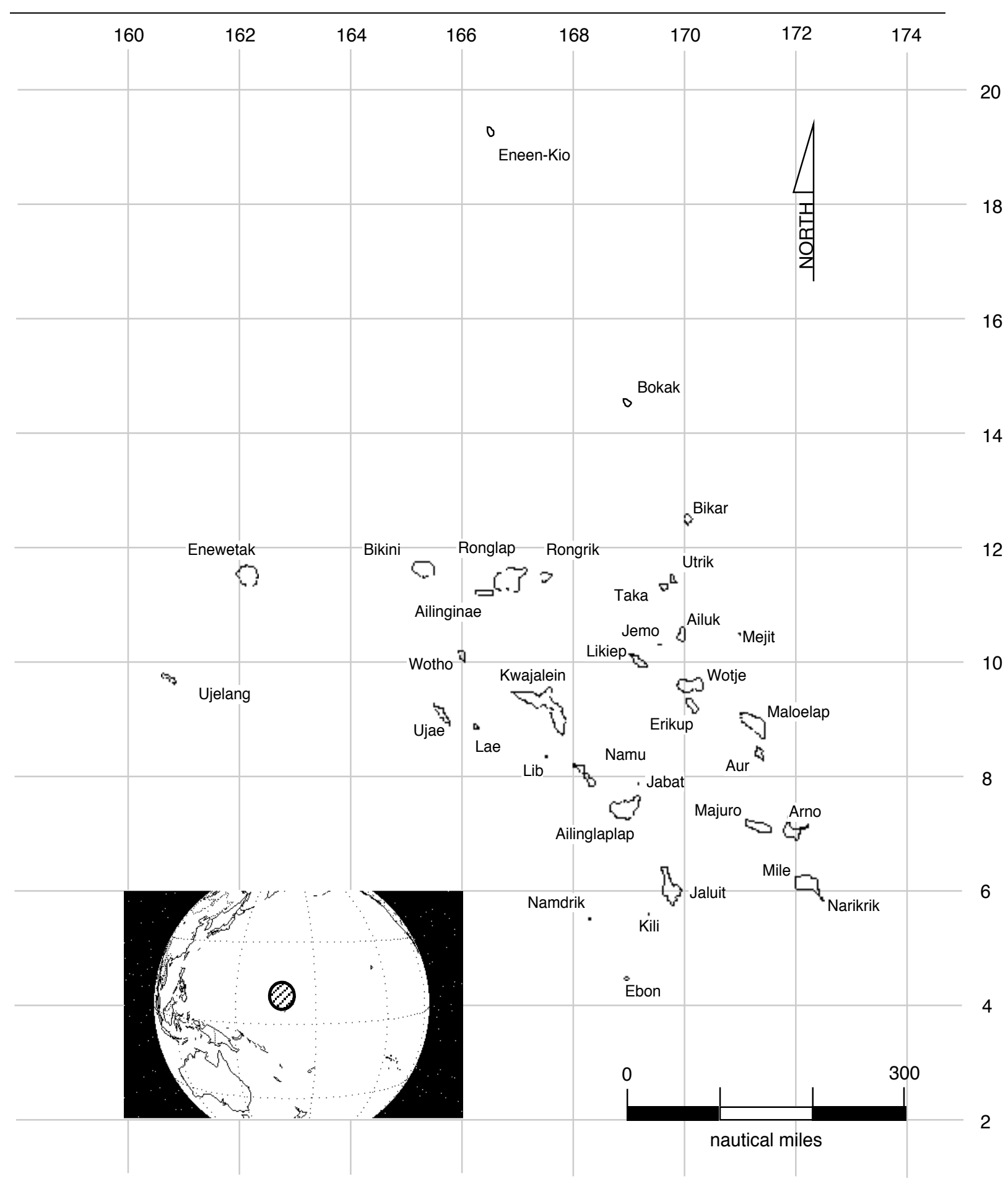

Figure 1. Index map of the Marshall Islands showing the atolls mentioned in the text. 


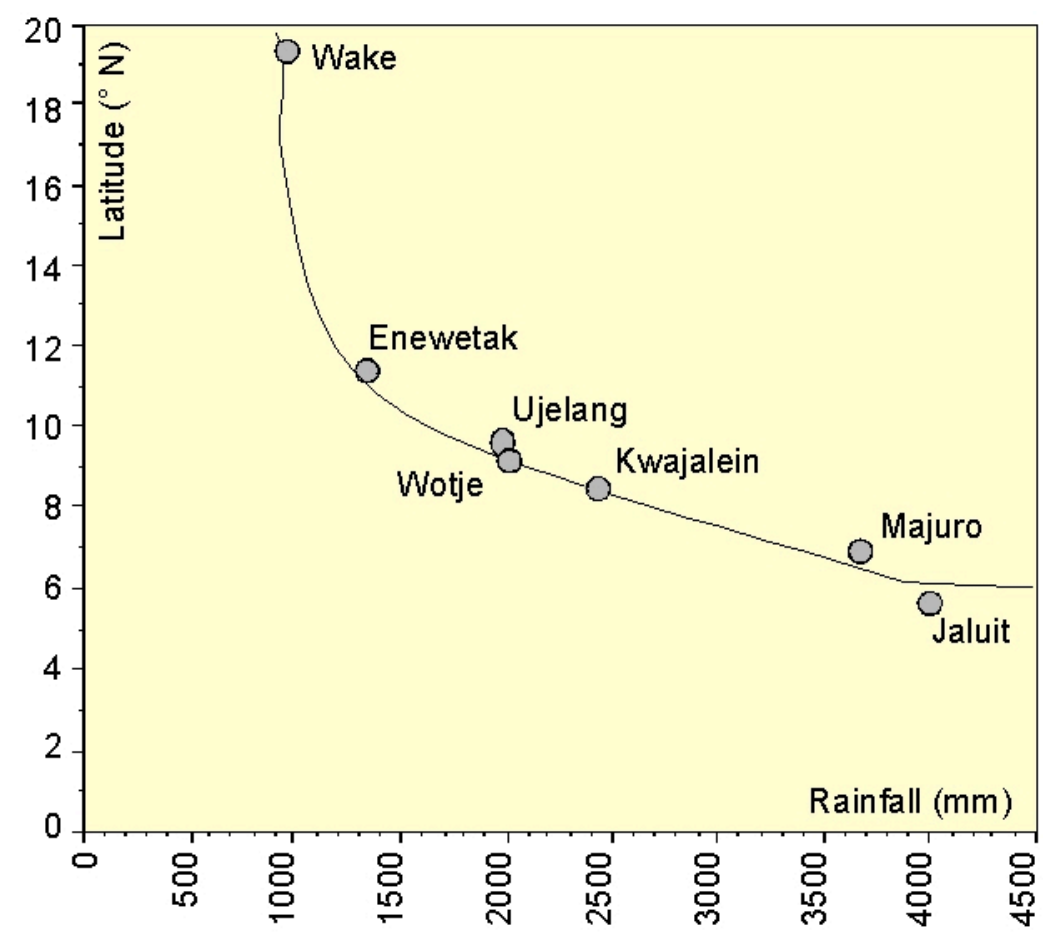

Figure 2. Relationship between annual average precipitation and latitude in the Marshall Islands area (Source: William \& Sabbath 1982; image from Spennemann 1992).

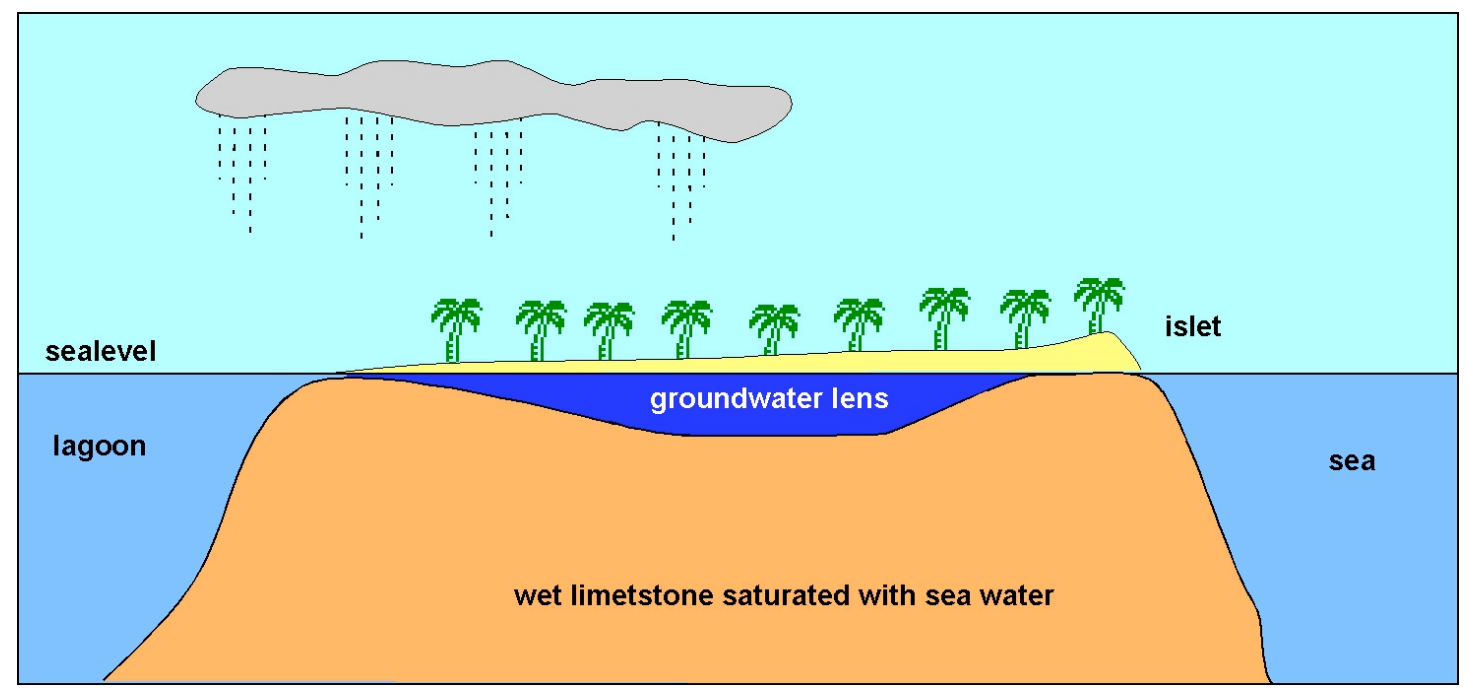

Figure 3. Concept of the freshwater lens. 


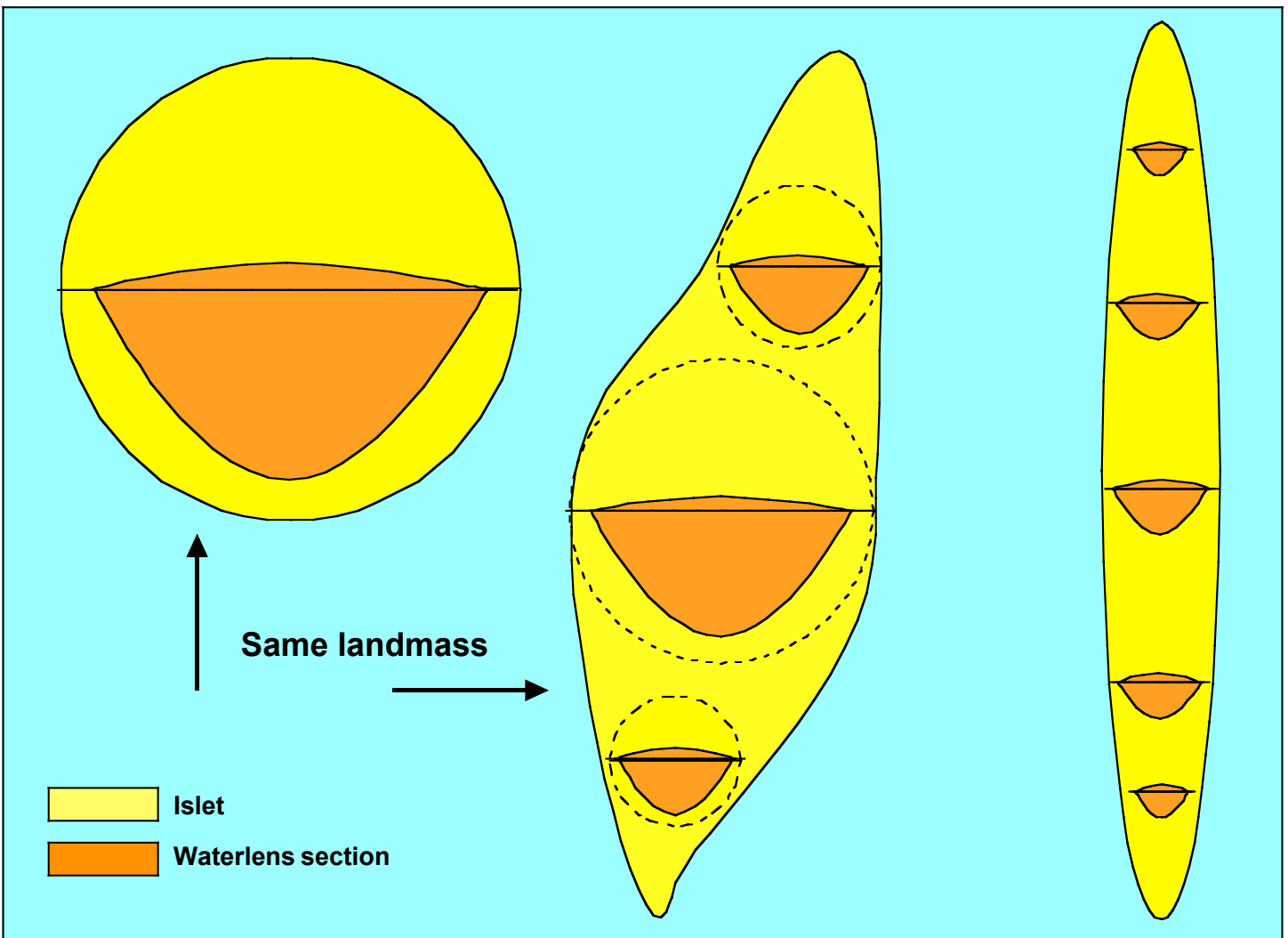

Figure 4. Conceptual relationship between island size, island shape and water lens.

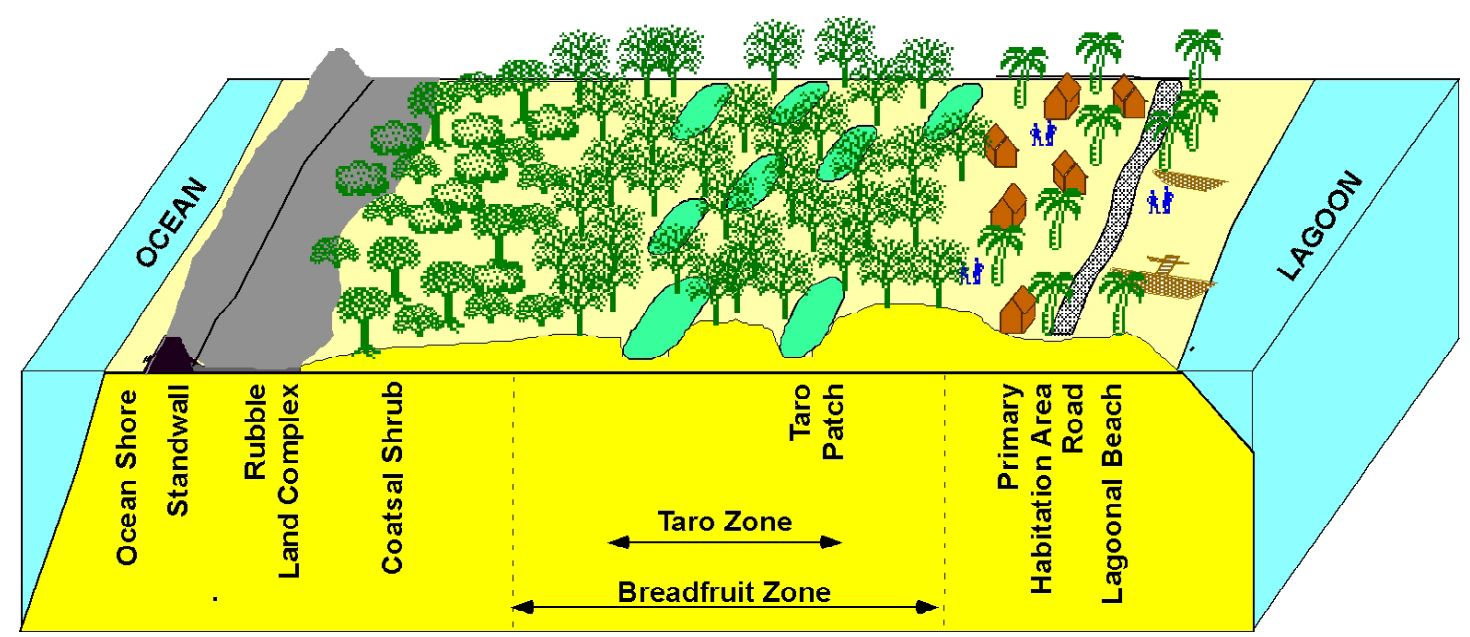

Figure 5. Schematic representation of the vegetation zonation across a leeward atoll islet in the central and southern Marshalls (after Spennemann 1990 with modifications). 


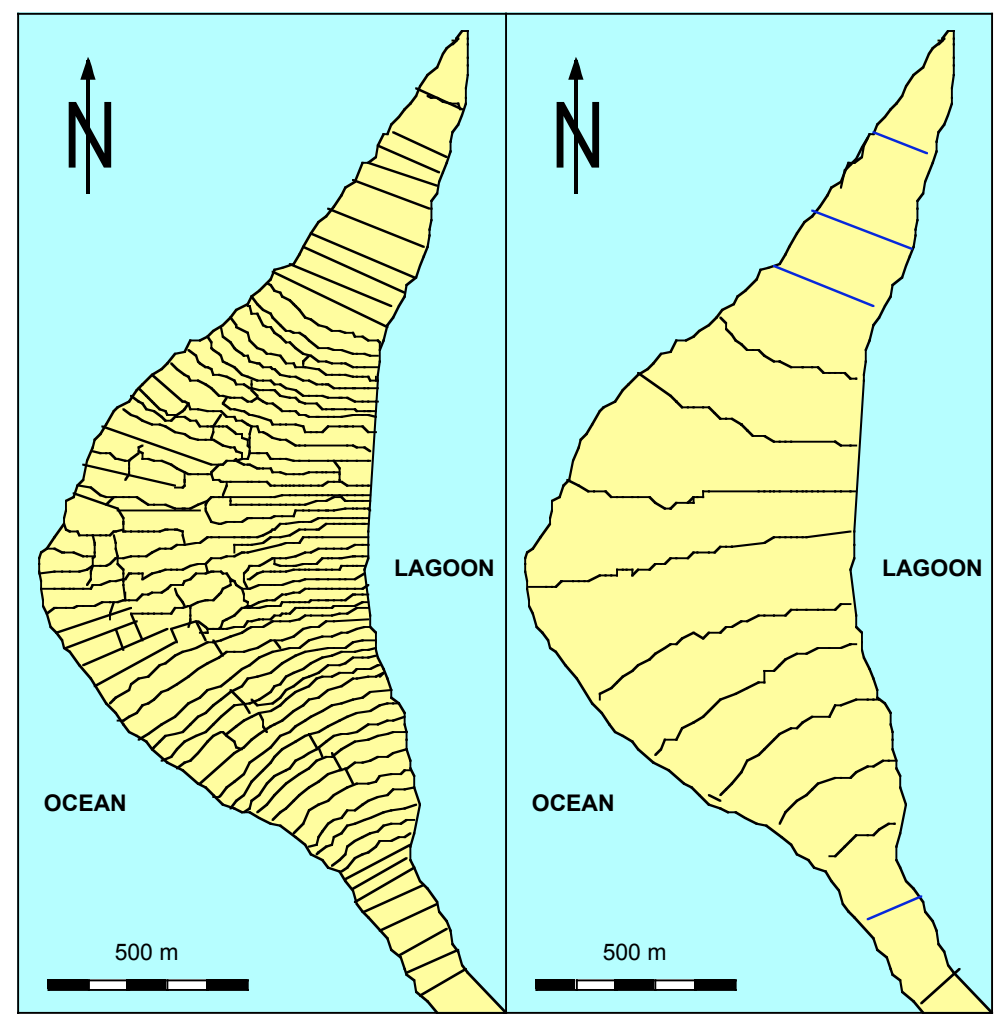

Figure 6. Land Allotments on Majuro Islet ('Laura'), Majuro Atoll. Left: allotments as they appear today. Right reconstructed size and appearance of allotments based a reversal of the fission sequence (after Spennemann 1990).

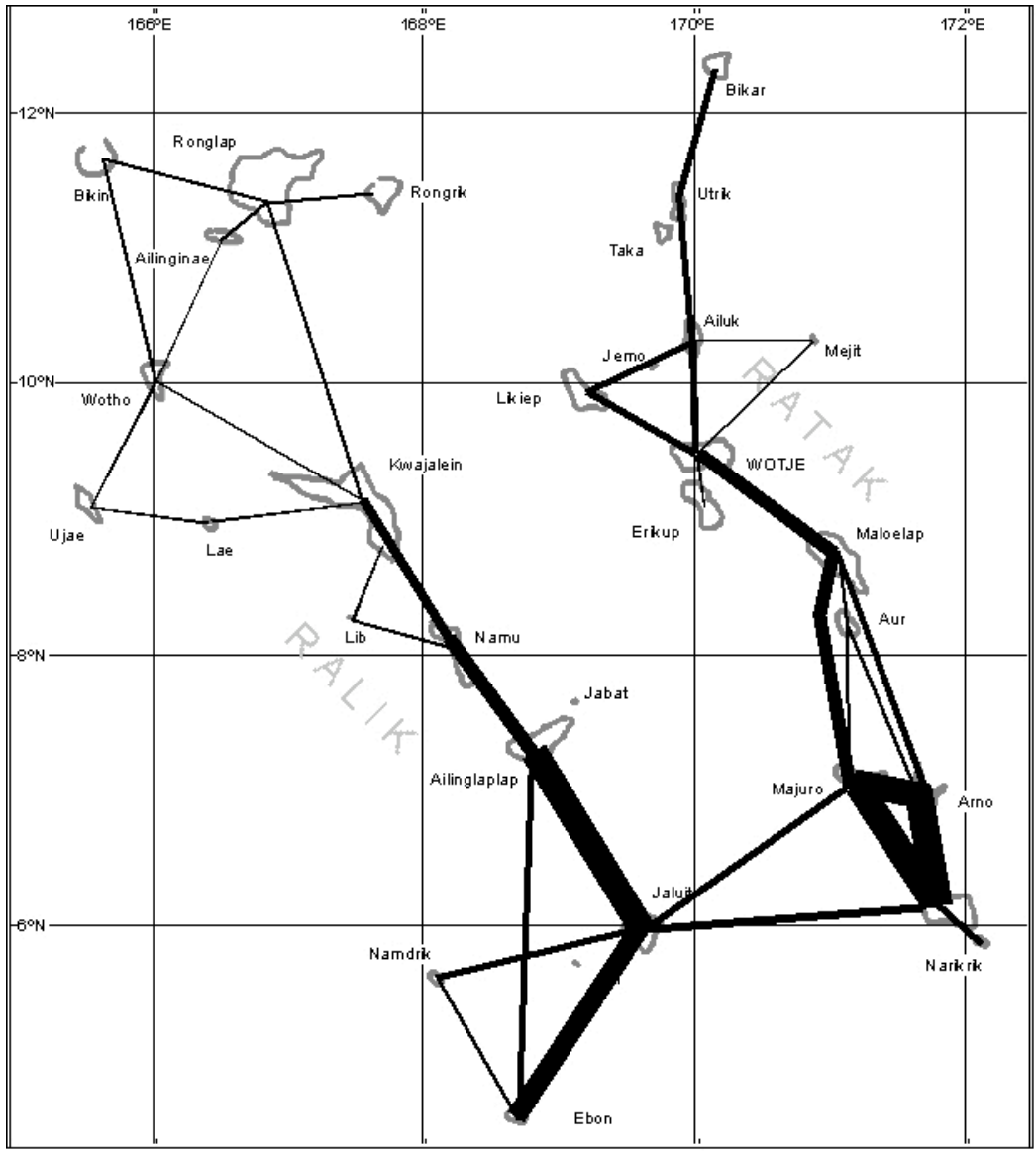

Figure 7. Connectivity in the early contact Marshall Islands. The strength/frequency of the connections is expressed by the thickness of the lines (after Spennemann 2005). 


\section{References}

Anthony, S.S., Peterson, F.L., Mackenzie, Fred, T. \& Hamlin, S.N. (1989)

"Geohydrology of the Laura fresh-water lens, Majuro atoll: A hydrogeochemical approach”. Geological Society of America Bulletin 101(8): 1066-1075.

Arnow, T. (1954) "The Hydrology of the Northern Marshall Islands", Atoll Research Bulletin 30: 1-7.

Biermann, M. (1889) "Verordnung [des Kaiserlichen Landeshauptmannes] betreffend die Erhebung von persönlichen Steuern”. Jaluit, 15 October 1889. Ms. on file German Colonial Records, Bundesarchiv Berlin.

_ (1890) "Verordnung [des Kaiserlichen Landeshauptmannes] betreffend die Erhebung von persönlichen Steuern”. Jaluit, 17 April 1890, in Riebow, G. (1892) Die Deutsche Kolonialgesetzgebung. Sammlung der auf die deutschen Schutzgebiete bezüglichen Gesetze, Verordnungen, Erlasse und internationalen Vereinbarungen, mit Anmerkungen und Sachregister. Erster Theil bis zum Jahr. Berlin: D.Reimer.

Bryan, E.H. (1971) Guide to Place names in the Trust Territory of the Pacific Islands (the Marshall, Caroline and Marina Islands). Honolulu: Bishop Museum, Pacific Science Information Center.

Chamisso, A. von (1836) Reise um die Welt mit der Romanzoffischen EntdeckungsExpedition in den Jahren 1815-1818 auf der Brigg Rurik, Kapitain Otto v. Kozebue. Adalbert von Chamisso's Werke. Leipzig: Weidmann'sche Buchhandlung. 1842.

Cox, D.C. (1951) "The Hydrology of Arno Atoll, Marshall Islands", Atoll Research Bulletin 8: 1-31.

Drabbe, J. \& Badon Ghijben (Ghyben), W. (1889) "Nota in verband met de voorgenomen putboring nabij Amsterdam" Tijdschrift van het Koninklijk Instituut van Ingenieurs Verhandelingen (1888/1889).

Eisenhart, O. (1888) “Acht Monate unter den Eingeborenen auf Ailu (MarshallGruppe)", Aus allen Welttheilen 19.

Erdland, A. (1909) "Die Stellung der Frauen in den Häuptlingsfamilien der Marshall Inseln", Anthropos 4:106-112.

_ (1912) "Die Eingeborenen der Marshall Inseln im Verkehr mit ihren Häuptlingen", Anthropos 7: 559-565.

(1914) "Die Marshall Insulaner. Leben und Sitte, Sinn und Religion eines Südsee-volkes", Anthropos Ethnologische Bibliothek. Bd. 2, Heft 1. Münster i[n] W[estfalen]: Aschendorffsche Verlagsbuchhandlung.

Fosberg, F.R. (1990) "A review of the Natural History of the Marshall Islands", Atoll Research Bulletin 330. Washington: Smithsonian Institution.

Herzberg, A. (1901) "Die Wasserversorgung einiger Nordseebäder", Journal für Gasbeleuchtung und Wasserversorgung 44: 815-819; 842-844. 
Jeschke, C. (1905) "Bericht über den Orkan in den Marschall-Inseln am 30. Juni 1905." Petermanns Mitteilungen 51: 248-249.

Kotzebue, O. von (1830) Neue Reise um die Welt in den Jahren 1823, 24, 25 und 26. Weimar, Wilhelm Hoffmann und St. Petersburg, J. Brief. 2 vols.

Krämer, A.A. \& Nevermann, H. (1938) "Ralik-Ratak (Marschall Inseln)" in Thilenius, G. (ed.), Ergebnisse der Südsee-Expedition 1908-1910. II. Ethnographie, B: Mikronesien. Vol. 11: Hamburg: Friedrichsen \& de Gruyter.

Krämer, A. (1906) Hawaii, Ostmikronesien und Samoa. Stuttgart: Schweizerbartsche Verlagsbuchhandlung.

Riebow, G. (1893) Die Deutsche Kolonialgesetzgebung. Sammlung der auf die deutschen Schutzgebiete bezüglichen Gesetze, Verordnungen, Erlasse und internationalen Vereinbarungen, mit Anmerkungen und Sachregister. Erster Theil bis zum Jahr 1892. Berlin: D.Reimer.

Sonnenschein, F. (1888a) "Verordnung, betreffend die Erhebung von persönlichen Steuern". Jaluit, 28 June 1888. Ms. on file German Colonial Records, Bundesarchiv Berlin.

— (1888b) "Verordnung betreffend die zwangweise Eintreibung rückständiger Steuern. Jaluit, 11 Dezember 1888", in Riebow, G. Die Deutsche Kolonialgesetzgebung. Sammlung der auf die deutschen Schutzgebiete bezüglichen Gesetze, Verordnungen, Erlasse und internationalen Vereinbarungen, mit Anmerkungen und Sachregister. Erster Theil bis zum Jahr 1892. Berlin: D.Reimer (1893).

(1888c) "Verordnung [des Kaiserlichen Kommissars] betreffend die Art der Steuererhebung. Jaluit, 28 September 1888", in Riebow, G. Die Deutsche Kolonialgesetzgebung. Sammlung der auf die deutschen Schutzgebiete bezüglichen Gesetze, Verordnungen, Erlasse und internationalen Vereinbarungen, mit Anmerkungen und Sachregister. Erster Theil bis zum Jahr 1892. Berlin: D.Reimer (1893).

Spennemann, D.H.R. (1990) Cultural Resource Management Plan for Majuro Atoll, Republic of the Marshall Islands. 2 Vols. Report prepared in fulfilment of U. S. Department of Interior, Office of Territorial and International Affairs Technical Assistance Grant MAR-42. Report submitted to the Historic Preservation Office, Majuro, Republic of the Marshall Islands. August 1990, (printed 1992).

(1992) "Makmõk. Notes on the occurrence, utilisation, and importance of Polynesian Arrowroot (Tacca leontopetaloides) in the Marshall Islands". Republic of the Marshall Islands Ministry of Internal Affairs / Ministry of Social Services Occasional Paper $N^{o}$ 1. Majuro, Marshall Islands: Ministries of Internal Affairs and Social Services.

(1996) "Dreading the next wave: non-traditional settlement patterns and typhoon threats on contemporary Majuro, Marshall Islands", Environmental Management 20(3): 337-348.

_ (1998) "An officer, yes; but a gentleman? A biographical sketch of Eugen Brandeis, Military adviser, imperial judge and administrator in the German 
Colonial Service in the South Pacific" Pacific Island Studies Monographs Vol. 21 Sydney: Centre of South Pacific Studies, University of New South Wales.

(1999) "No room for the dead. Burial practices in a constrained environment", Anthropos 94(1): 35-56.

_ (2000) "Historic Demographic Information for the Marshall Islands - Period from 1891 to 1914 ", Albury.

$<$ http:/marshall.csu.edu.au/hmtl/demography/1891.html $>$.

— (2004) "Chamissos Blick auf die Südsee und die Rezeption der 'Reise um die Welt' im Südpazifischen Raum" in Mit den augen des Frenden. Adelbert von Chamisso-Dichter, Naturwissenschaffender, Weltreisender. Berlin; Gesellschaft für interregionalen Kulturaustauch .V. Berlin.

- (2005) "Traditional and nineteenth century communication patterns in the Marshall Islands", Micronesian Journal of the Humanities and Social Sciences 4(1): 25-51.

— (in prep). From Disaster to Disaster...The efforts of the German Colonial Administration in Micronesia to mitigate the effects of the typhoons of 1905 and 1907. Book manuscript.

Tobin, J.E. (1952) "Land tenure in the Marshall Islands", Atoll Research Bulletin 11. Washington: Pacific Science Board, National Research Council.

- (1958) Land tenure patterns Trust Territory of the Pacific Islands. Volume 1. Land tenure in the Marshall Islands. Guam: Office of the Staff Anthropologist, Terrritory of the Pacific Islands.

Wheatcraft, S.W. \& Buddemeier, R.W. (1981) “Atoll island hydrology”, Ground Water 19(3): 311-320

Williamson, I. \& Sabath, M.D. (1982) "Island population, land area, and climate: A case study of the Marshall islands", Human Ecology 10(1): 71-84.

\section{Biographical Note}

A/Prof Dirk Spennemann (PhD ANU) was the government archaeologist of the Marshall Islands (1989-1993) and has extensively published on the history and cultural heritage Micronesia, in particular the Marshall Islands and the Marianas. He has just completed a book on the history of typhoons in Micronesia (until 1914) and is in the process of competing a study of the impact of typhoons on atoll populations in Micronesia.

for full CV see $<$ http://csusap.csu.edu.au/ $\sim$ dspennem $>$. 